\title{
Does the Papal Doctrine on Sport Exert Influence on Theologians in the Czech Republic? (An Analysis of Survey Results) Vojtěch Svoboda
}

\section{Introduction}

The popularity of sport has for several decades been an unmissable feature of society. That is one of the reasons why many Popes have also devoted extensive space to it in their speeches. The first part of the study presents the way in which sport is evaluated in texts by John Paul II and Benedict XVI, who paid the greatest attention to it. In the second part the author presents seven questions concerning the body and sport to theologians in the Czech Republic. The text aims to provide a comparison of these two types of statements and in this way determine possible differences in the issue of the theological evaluation of sport. ${ }^{1}$

\section{Goal, problem areas, and methodology}

The first part of this study describes the way in which sport was evaluated by Popes John Paul II and Benedict XVI, who devoted extensive space to it during and before their pontificates. Their statements can thus be regarded as one of the starting points for a new theological discipline - the theology of sport. The basic source for describing the evaluation of sport by Pope John Paul II are his homilies, Angelus messages, speeches at sports events and letters from 1978-2005 collected in The Pastoral Messages (Homilies, Angelus Messages, Speeches, Letters) of Pope John Paul II That Refer To Sport (1978-2005). Information on Benedict XVI's evaluation of sport is drawn especially from the study Sporting Activity in the Thought of Joseph Ratzinger/Benedict XVI. ${ }^{2}$

The second part presents statements made by contemporary theologians in the Czech Republic. For this purpose a selection was made of available theological authorities including responsible persons of the Czech Catholic Church, some professors, associate professors and lecturers of the theological faculties of Czech universities (Faculty of Theology of University of South Bohemia in České Budějovice, Catholic Theological Faculty of the Charles University in Prague, Protestant

1 The paper is one of the outputs of the two year project Catholic Theology of Sport (reg. no. 115/2013/H); the project was financially supported by the Grant Agency of the University of South Bohemia.

2 Joseph CLEMENS, Sporting Activity in the Thought of Joseph Ratzinger/Benedict XVI., a text sent by email by K. Lixey, LC, who in 2004-2012 directed the department of Church and Sport of the Pontifical Council for the Laity. 
Theological Faculty and Hussite Theological Faculty of the Charles University in Prague, and Sts Cyril and Methodius Faculty of Theology of the Palacký University in Olomouc). Two Catholic bishops also took part in the survey. The goal of this part of the research was to find out through the answers received how the respondents perceive the human body and sport as one of the mass phenomena of the present age. The Christian view of bodily culture has undergone extensive historical development. This survey helps to clarify what the nature of this relationship is at present in the Czech Republic. The author thinks that the perception of the human body can be conceived as the general framework for evaluating sport. That is why the first questions are aimed at the body from the point of view of theological anthropology and the subsequent ones concern sport as such.

Out of the 42 persons originally addressed, 23 respondents took part in the survey. Among the respondents there were five persons with a master's degree, six with a doctor's degree, seven associate professors and five professors. With the exception of two of the persons addressed the respondents lecture at Czech universities as internal or external lecturers. Three respondents hold the office of bishop. The reason why ten of the persons addressed did not take part in the survey was in some cases that they regarded the topic as insignificant, and others did not feel competent to express their view or found the questions too ambiguous. The other persons addressed did not react to the request for participation in the survey, and in five cases the communication ended upon receiving the questions.

The basic investigative method selected was the form of structured questioning, which took place by personal, phone and electronic communication. The data was collected and other communication took place in the second half of 2014, when the following questions were presented to the participants:

1) What is the human body?

2) What is the purpose of the body in this world?

3) What does Christ's risen body mean together with his promise of exalting our bodies?

4) Can the body and the soul be separated?

How can the reality of an immaterial soul in a material body be grasped?

5) What role and at what levels does physical movement play for a Christian (spiritual, biological, social, etc.)?

What is your view of sport from the point of view of spiritual practice? Can it be regarded as a form of the effort to get closer to God?

6) What is your view of sport in its positive and negative aspects?

7) Do you see a deficiency in the theological investigation of the body, bodily movement and the phenomenon of sport?

The selected method is a case of mixed research in which the author combines aspects of qualitative and quantitative research. This type facilitates a better grasp of the investigated topic than when one of the approaches is chosen. Collecting data by structured questioning relied on quantitative methods, analysing and categorising the data corresponds to the rules of qualitative research. The interpretative effort was to find the features shared by the answers and thereby to create the categories that were found in the statements. 
This study aims to provide the possibility of comparing two types of answers: the evaluation of sport by the above-mentioned Popes based on their letters and speeches and its evaluation by contemporary Czech theologians. While in the case of questionnaires it is possible to use direct answers or passages from them, this is not possible in the case of papal statements. That is why the author has attempted to highlight the elements and thoughts that appeared in the texts most frequently. The author has already undertaken an interpretation of the papal evaluation of sport in his master's thesis. ${ }^{3}$ This study indirectly follows up on this text.

\section{Sport through the eyes of the Popes}

To present the attitude of the Popes to sport, the author selected John Paul II and Benedict XVI, who devoted the greatest space to it in their texts. A part of Benedict XVI's texts comes from the time before his pontificate. The key to understanding the following papal statements is the Christian vision of the human being. According to this doctrine, based on the event of Creation in the book of Genesis, human beings are created in the image of God (Gen 1:26-28). At the same time they were created as a unity of body and soul. God created both and deemed them good (Gen 1:31). Not the body or the soul individually, but only both of the components together constitute the entire human being. In that way the aggregation of body and soul can be regarded as an essential goal of the human being and their separation must be regarded as bad. Only in that way can being created in God's image correspond to particular human existence.

\section{John Paul II}

There are many sources confirming Pope John Paul II's purely positive relationship to sport, including his rich personal experience. ${ }^{4}$ His positive evaluation can also be inferred from the number of sporting events he took part in during his pontificate. ${ }^{5}$ On these occasions he delivered speeches with which he spread the Church's message also to the sports world. Although the Pope did not elaborate a theology of sport, his numerous messages and statements are among the foundations on which this young discipline can rely. ${ }^{6}$ In texts dealing with sport he frequently highlighted certain elements, which can thus be regarded as the core of his sport-theological reflections. Besides the harmonious development of the human being he laid a special emphasis on sport as a means to transcend borders both at the level of individuals and on a global scale.

Sport is sometimes perceived primarily as developing the bodily component of the human being or as an instrument of reinforcing physical health. The Pope esteems this element highly. But at the same time he remarks that sport develops the human being in his entirety, comprising of body and soul: 'Not only does the player find, on the level of the body, the relaxation that he needs, not

3 Vojtěch SVOBODA, Teologie a filosofie sportu se zřetelem k americkému fotbalu, diploma thesis, University of South Bohemia in České Budějovice, České Budějovice, 2011.

4 It may be interesting that, as the contemporary director of the department of Church and Sport of the Pontifical Council for Laity S. C. de Perez informed the author of this paper in private communication during his visit to the Vatican in November 2013, Pope John Paul II had the local heliport rebuilt as a tennis court.

5120 sports events. Private communication of S. C. de Perez, November 2013.

6 The texts by John Paul II used in the paper come from Kevin LIXEY, Norbert MÜLLER and Cornelius SCHÄFER, The Pastoral Messages (Homilies, Angelus Messages, Speeches, Letters) of Pope John Paul II That Refer To Sport (1978-2005), Vatican: John Paul II Sports Foundation, 2012. 
only does he acquire additional suppleness, skill and endurance, and strengthen his health, but he grows in energy and in the spirit of teamwork.'7 And also, 'Yes, like so many other sports, football can elevate man.'

However, he finds the most essential contribution of sport at the interpersonal level. This is not only manifested at the level of individual relationships, but can lead to crossing the barriers between whole nations: 'sport can certainly contribute to helping the participants get to know one another better, appreciate one another, and experience a certain solidarity beyond frontiers, precisely on the common basis of their same human and sporting qualities.'

Or elsewhere he said: 'Let your gathering be a symbolic sign for the whole society and a prelude to this new age, in which nations "shall not lift up sword against nation" (Isa 2:4). ${ }^{\text {'0 }}$

One of the essential features of sport is its competitiveness. The Pope often appealed for its purification to maintain its proper - humanly healthy - form: A sense of brotherhood, generosity, honesty and respect for one's body - virtues that are undoubtedly essential for every good athlete - help to build a civil society where antagonism is replaced by healthy competition, where meeting is preferred to conflict, and honest challenge to spiteful opposition. ${ }^{11}$

But alongside the positive aspects John Paul II does not forget to remind us of the dangers threatening the world of sport. Among the most frequently mentioned are its commercialisation, corruption, and others: '...from the obsessive preoccupation with gain to the commercialization of almost every aspect of sport, from the excessive emphasis on the spectacular to athletic and technical exhaustion, from the use of doping and other forms of fraud to violence.'12

\section{Benedict XVI}

Pope Benedict XVI also provides a number of statements suitable for a theological reflection of sport. Bishop Clémens states that in the first two and a half years of his pontificate the Pope touched on the topic of sport in more than fifty instances. ${ }^{13}$ As he explains himself: 'during the Pontificate of Pope Benedict XVI, the interest and concern of the Universal Church to the vast world of sport continues as it seeks to dialogue with the renowned sports institutions at the international level while fostering a renewal of pastoral work in and through sports...' ${ }^{14}$

In connection with football Cardinal Ratzinger had already before his pontificate underlined its global character and at the same time its massive influence on humans all around the world: Football has become a global event which has brought men from all around the world across all

7 JOHN PAUL II, Human and Sporting Qualities Make Men Brothers. To the meeting of UEFA representatives in Rome on 20 th June 1980.

8 Ibid.

9 Ibid.

10 JOHN PAUL II, The Most Authentic Dimension of Sport: To Create a New "Civilisation of Love", homily at the Olympic stadium in Rome, 12th May 1989.

11 JOHN PAUL II, Jubilee of Sports People Address of John Paul II to the International Convention on the Theme: "During The Time of the Jubilee: The Face and Soul of Sport", 28th October 2000.

12 JOHN PAUL II, Stadium Blessing Marks Start of International Playoffs: Pope John Paul II Inaugurates 'ITALIA 90' Cup, 31st May 1990.

13 Joseph CLEMENS, Sporting Activity in the Thought of Joseph Ratzinger/Benedict XVI.

14 () Joseph CLEMENS, Sport in the Magisterium of Benedict XVI (on-line), at: http://thesportjournal.org/article/sport-in-the-magisterium-of-benedict-xvi/, actualised 28th February 2013, accessed 14th April 2015. 
boundaries into one and the same 'place for the soul', where they are united by hopes, anxieties, passions and joy. Hardly any other event on earth can achieve a similar widespread effect. ${ }^{15}$

Analysis of sport leads him to its radical freedom allowing for a stepping out of the necessity of everyday life. In this sense he designates sport as a foretaste of paradise: 'In this sense, sport becomes a sort of foretaste of Paradise: a stepping out of the slavish earnestness of our daily life and its concerns into the free seriousness of something that should not be serious and is therefore beautiful. In that way sport overcomes daily life. ${ }^{16}$

Benedict XVI repeatedly underlined that the freedom in sport is not absolute, but rule-based. ${ }^{17}$ In that way sport becomes a school of life, which through training teaches self-control, by which the sportsperson can attain freedom..$^{18}$ Cooperation is another positive aspect of sport. Sports, especially collective ones, provide a common goal contributing to the development of the whole community: 'sports, practised with enthusiasm and an acute ethical sense, especially for youth become a training ground of healthy competition and physical improvement, a school of formation in the human and spiritual values, a privileged means for personal growth and contact with society.' ${ }^{\prime}$

Similarly in a letter to Cardinal Rylko he writes: In our time when an urgent need to educate the new generations is evident it is therefore necessary for the Church to continue to support sports for youth, making the most of their positive aspects also at competitive levels such as their capacity for stimulating competitiveness, courage and tenacity in pursuing goals. ${ }^{20}$

In his speech to the Austrian national skiing team the Pope summarises that 'sport helps man to consider his own capacities as a talent and his life as a gift of God. Even when sport is practiced at high levels, it is important to maintain an inner harmony between body and spirit in order not to reduce it to a mere search for results. ${ }^{21}$

\section{Topical answers: The human body - unity and diversity}

The survey analysis begins by presenting the answers to the first question: 'What is the human body?' How is the essential material existence of the human being perceived? Answering this question appears to be the starting point for the possibility of further statements concerning the body.

15 ( ) Joseph RATZINGER, Football Can Be More Than Just Entertainment (on-line), at: http://freeforumzone.leonardo.it/discussione. aspx?idd=354533, accessed 15th March 2015.

16 Ibid.

17 (c) Joseph CLEMENS, Philosophical Foundations of the Sporting Phenomenon (on-line), at: http://thesportjournal.org/article/ sport-in-the-magisterium-of-benedict-xvi/, accessed 16th March 2015.

18 Cf. () Joseph RATZINGER, Football Can Be More Than Just Entertainment.

19 BENEDICT XVI, L'Osservatore Romano, Speech to the Participants of the World Swimming Championship, 2009.

20 (c) BENEDICT XVI, Message of His Holiness Benedict XVI To Cardinal Stanislaw Rylko, President of the Pontificial Council For the Laity on the Occasion of the International Study Seminar on: "Sport, Education, Faith: For a New Season for the Catholic Sports Movement" (on-line), at: http://www.vatican.va/holy_father/benedict_xvi/messages/pont-messages/2009/documents/hf_ben-xvi_ mes_20091103_rylko-sport_en.html, accessed 15th March 2015.

21 (c) BENEDICT XVI, Sport Must Not Be Reduced to a Mere Search for Results (on-line), at: http://www.freeforumzone.com/discussione. aspx?idd=354494\&p=132, accessed 20th March 2015. 
The most frequent answers emphasised the psychosocial unity of the human being. In this context $\mathrm{R} 1$, a professor and ordained evangelical minister, refers to the ideas of Karl Barth when he answers: 'The human being is created in psychosomatic unity, as body and soul, the soul is primary in some respect..., but it is impossible to conceive both body without soul, and soul without body.'

R2, a lay person lecturing at the Faculty of Theology, University of South Bohemia in České Budějovice: "The human body is really a temple of the spirit, the "instrument" of the soul and the spirit for activity at the material level. The relationship of the body to the higher spheres of the human being is approximately similar to the relationship of the skeleton to the "finer" bodily systems, such as muscles, nerves, etc. The human body is a creation of an amazing intelligence, which is in fact continuously working on creating it, as human evolution allows us to see. It is given to the human being so that he can be active with it here on Earth and thereby transform it (and himself) to ever greater perfection.'

All answers manifested admiration of the body as created by God and perfect on Earth. The most frequent answer to this question referred to the unity of psyche and soma, two concepts commonly employed in theology. In the Christian tradition the human being is commonly conceived as a unity of body, soul and spirit. But the emphasis on including the third element has undergone a certain development and so the human spirit has become the object of many debates. ${ }^{22}$ But does this anthropological division provide a real answer to the question raised above?

The second question 'What is the purpose of the body in this world?' follows up on the preceding one. The human being has subdued the Earth in a body that is vulnerable as compared to animal bodies. Nonetheless, its variability facilitates life all over the planet. The body makes it possible to fulfil various human needs and plans, to many of which it functions as a motive. How do theologians answer the question concerning the purpose of the human body?

With some exceptions most of the respondents stated two essential purposes of the human body. One of them is communication with others. In this way the body is conceived as the soul's mediator for its encounter with this world and at the same time with other souls.

$\mathrm{R} 3$, associate professor of the Catholic faith, states in this context: 'If I conceive the human being as the lowest of spiritual beings, then the human body is in fact a bridge between the spiritual aspect of the human being and the material world.'

Another frequently emphasised purpose is the existence of our body as a form of serving God. This is grounded by the Biblical creation of the human being in the image of God.

R4, a professor and ordained evangelical minister, states in this context: '... All that we do in the body (work, family, etc.) is to serve our neighbours, God's glory, and we can experience everything sub specie aeternitatis.'

Probably the strongest comment in this sense was made by a member of the Orthodox Church community of České Budějovice and Jindřichův Hradec, R5: 'To reach theosis - being like God -

22 The biblical tradition speaks of the spirit with the terms ruach or pneuma. The term is frequently used for example by Apostle Paul; it came into focus especially at the eighth ecumenical council. 
together with the human soul and spirit.' But he supplements the statement with the explanation that the human being will not become a god, like iron pressed to a magnet does not become a magnet, merely receiving its properties in a certain way.

Another recurrent feature of the answers was the necessity of our death. An associate professor of the Catholic faith, R6, notes on this point: '... the doctrines of the first Councils - especially the ones in Ephesus and Chalcedon - unambiguously point to the fact that the "body", or the real "physical" or "human" existence of Christ was emphasised as an entirely fundamental matter: without his physical suffering and death we could not be saved. For me this implies that the body is of fundamental significance: we must die, in order to live with Christ after death - and that is the end or purpose of the human body ..., the human being must die in order to be able to live with Christ after death. So death can be conceived as the final purpose of the human body in the hope of resurrection.'

The death and resurrection of Jesus of Nazareth is the core of Christian doctrine. Faith in the resurrection of the body is the subject of a substantial part of Christian dogmatics. From this point of view the eschatological dimension of human existence takes on an importance. So the third question makes up a logical continuation of the statements. In connection with Christ's resurrected body theologians are accustomed to speak of a different ontological level of existence. That is how most respondents speak.

R4 says: 'Christ's risen body is not subjected to the physiological and biological laws of space-time and Christ's resurrection opens up an eschatological perspective of participation in Christ's glorified body (1 Cor 15:20-58).'

R3 continues: 'It is evidence that for God matter is not something impure, so that through Christ's humanity (including his materiality) it could even be united to his divinity. At the same time (if we are speaking of the resurrected body) it is real evidence (the apostles touched it) that the promise of the glorification of the human being including his corporeal nature is not a mere metaphor or a misunderstanding.'

Some of the respondents answered in a broader social context of the resurrection. Here the social level of the resurrection event becomes the true core of the resurrection doctrine, viz. the elevation of all humans, all humanity. In this sense R7, a bishop of the Czechoslovak Hussite Church, answers: 'It signifies the reality of the Resurrection, which concerns the human being in his entirety. It is a promise of resurrection for all those who accept Christ's path.'

R2 says: 'Christ's risen body is an expression of his triumph over death. By his spiritual strength, by his life, Christ triumphed over the powers of death and emancipated himself from their influence. Thereby his body also became independent of the powers of death and was elevated to the level of immortality... On hearing Christ's summons to discipleship we will be gradually filled by His power and life to the extent that one day we will also be emancipated from the influence of death and our body will not be subject to it any more. That is resurrection.'

Body and soul are normally regarded as the basic components of the human being. At the time between birth and death, the human being and his body can be regarded as equal. Despite that 
the ancient and Biblical tradition assumes that the human body does not differ from the bodies of other living beings merely by its structure, but also by its quality or essence, which is traditionally labelled the 'soul'. If a statement is made about the human being from the point of view of the above-mentioned anthropology, the term 'soul' is normally employed as that part of the human being that is not subjected to the destruction of the body. The next question dealt precisely with these two components and their mutual relationship.

R8, a Catholic associate professor, explains how this issue was viewed in the past: 'The relationship of the soul (spirit) and body has been the subject of extensive debates that have been going on for already several thousand years. In these debates several views of the body-soul relationship are encountered: 1. Aristotelian-Thomistic = the soul is the "forma formans corporis" or, according to Boëthius, "substantia spiritualis, identice permanens, causa et substratum actuum psychicorum"; 2. Biblical-oriental = the soul is the animating principle (nishmat chajjim = the breath of life); 3 . Materialistic = the soul is identical with the central nervous system.'

The answers agreed on this point. None of the respondents admitted a real separation of body and soul in the human lifetime. Following up on the first question the human being is conceived as a composite, within which the soul is in a certain sense regarded as the component motivating the material body. According to all respondents the real separation of the two components is only possible after death.

This is how R5 answers: 'The popular expression "soul" really refers to the human spirit, ..., which separates from the body at the moment of death... The soul is the enlivening principle, which also leaves the body, which is manifested precisely by the fading of life and gradual decay. The reality of an immaterial soul (or Spirit) in a material body cannot be grasped and it is not necessary...'

But some of the respondents hinted at the possibility that the relationship may be 'loosened' in some respect. R9, a bishop of the Catholic Church, regards his attitude to this issue as highly reluctant and states that he does not believe in a complete separation of the soul from the body, although he does admit the possibility of a certain 'loosening'. Such a possibility is also acknowledged by another bishop, R10.

A highly interesting explanation of this duality in some sense is provided by R2: '... The immateriality of the soul and the material body may sound far too contradictory. When we imagine or say that the body is a materialised, condensed spirit or a materialised "part" of the soul, or vice versa, that the soul is a very fine, spiritualised matter (that as yet cannot be scientifically examined), then it does not sound so contradictory and dualistic any more...'

The soul is conceived as the enlivening principle without which the body perishes. At the same time the identity of a human being is conserved only in his entirety. The usual answer spoke of the corruption of the body after the separation of the soul. A reverse explanation was provided by R3: "The human soul is so fashioned that it can communicate and acquire new knowledge by means of bodily functions. When deprived of the body it is solipsistically imprisoned in itself. Only God gives meaning to the immortality of the soul in the sense of surviving the death of the body, by enabling the separated soul (after death and before resurrection) to communicate (by supplying the missing mediation of the body by his activity)...' 


\section{Topical answers: Sport - a way to God?}

In connection with sport, its beneficence for human bodily health is often mentioned in society. Sport as such, for example in ancient Greece, probably arose on a religious basis. There still are religions for which movement (often in the form of dance or ritual combat) is a direct instrument to attain a spiritual experience. Even in contemporary modern society there are still many instances when athletes reach an altered state of consciousness in the course of their performance. In their own words they undergo experiences that are rather spiritual in character. ${ }^{23}$

The issue of the possible transcendental element in sport can at present be regarded as one of the main topics of theology of sport. ${ }^{24}$ The answers to the following questions are intended to clarify what stance Czech theologians take on this issue.

According to R8, sport leads to: '.. finding, accepting and developing oneself, even to self-transcendence. If such self-acceptance and self-development can be conceived as a path to God, then sports performance also heads towards this path.'

More than half of the respondents did not deny the possibility of a certain spiritual load in sport. At the same time the respondents stated certain conditions allowing such spirituality to be enabled. One of the frequent conditions was that sport does not stand in the way of the individual's spiritual needs.

One of the answers was: 'In sport one exceeds one's limits, which is a characteristic feature of probably all kinds of spiritual practice. Adequately practised bodily exercise (and therefore also sport) contributes to bodily beauty and beauty is without doubt one of God's attributes, so by sport we come to beauty and bodily perfection, which can certainly mean that by sport we come to God. However, only assuming that the means does not become the end.'

R9 evaluates the role of sport in Christian life primarily functionally. According to him, sport is an activity that is beneficent for the body and thereby for human health. Furthermore, a properly functioning body is normally the basic condition for performing vocations serving persons in need.

R1 takes a rather neutral stand on this issue: 'Perhaps some theological ethics will touch on sport, but only marginally - unlike for example art or science and technology. As such sport is "religiously neutral", it leads neither to God nor away from God, it can be good for Christians but only relatively.'

R5 answers rather more guardedly on this point: 'Since the desert fathers were the greatest experts on spiritual life, we can start from their experience that the body must be maintained in at least a sufficiently functional state so that one can engage in prayer and handiwork (making a living). Of course,

23 For example the type of experience known as flow. For further information see Michael MURPHY and Rhea WHITE, In the Zone: Transcendent Experience in Sport, New York: Penguin Book, 1995.

24 Indirect discussion takes place, for example, between Rev. Dr. L. Harvey, who advocates an 'autothelic' theory of sport, and Rev. Dr. R. Ellis, who expresses the view that in modern society sport helps to fulfil the needs that were formerly reserved to (organised) religion. For more information see Robert ELLIS, The Games People Play, Oxford: Wipf and Stock, 2014; Lincoln HARVEY, A Brief Theology of Sport, Oxford: SCM Press, 2014. 
the great ascetics mortified the body more, because they know from experience that spiritual strength and bodily strength are indirectly proportional. Excessive care of the body lulls the spiritual life. As for sport, it belonged in the ancient circus, and was not part of spiritual theory or practice.'

One of the topics that the Popes in the pre-Vatican II era had focused on is the ethical evaluation of modern sport. Pope Pius XII wrote on this topic in 1945 in his letter How the Culture of Sport Can Contribute to the Formation of Youth, and ten years later in his text Virtues for the Sports Education of Christians. ${ }^{25}$

Today, sport, as an activity contributing to general health in the sense of physical, mental and social well-being, can compensate for the lack of exercise brought about by social development and lifestyle. Another positive aspect is without doubt a certain ability to overcome barriers, both internal and external. ${ }^{26}$ Like all other branches of human activity sport also reflects that aspect of the human being that is regarded as a consequence of his fall. The following question aimed to find out what the respondents view as the main pros and cons of contemporary sport.

R5 answers: 'One learns inner discipline and perseverance, which are skills that can be put to good use when one decides for a spiritual life. Especially in Syria, the monks used sports terminology for their spiritual struggle.'

R9 also praises the ascetic element in sport. However, the respondents were also aware of a number of risks and negatives that can be attached to sport. As far as the negative elements in sport are concerned, an associate professor lecturing at the Faculty of Theology, University of South Bohemia in České Budějovice, R11, indirectly speaks of a phenomenon that is commonly labelled 'civic religion' when he says: 'It can even become a substitute for God, sport or sportspersons can be deified, as can the sports experience (adrenaline), etc.'

R3 points out exchanging the path for the goal: '... sport is a great thing, but it must not become a cult of health, or a cult of the body, or an inexorable rush after money or ever greater performances regardless of health and social context.'

In this way the theologians criticise the body cult, disproportionate financing and doping. Most of these negative aspects have to do with the development of some pathological features of the society as a whole. It is necessary to add that these elements are apparent especially in professional sport. R2 concludes the answer to this question as follows: 'Sport as a method is de facto neutral. It depends on how the human being makes use of it, on our intentions, goals, only they bring along positive or negative aspects when they are related to something.'

At the end of each interview some space was devoted to the question of whether the individual respondents perceive a deficiency in the theological investigation of this field. Most respondents (16) answered affirmatively, five took a negative stance. Only two stated that they don't know the answer.

The added statements spoke of a deficiency, or even, according to R3: 'Unambiguously so - a

25 How the culture of sport can contribute to the formation of youth, in: Sport in Magisterium of Pius XII, Kevin LIXEY. Unpublished text sent by Rev Kevin Lixey in an email communication on 11th October 2013.

26 John Cassian speaks of the athlete as an ideal exemplar and source of inspiration for future monastic life. Cf. Patrick KELLY, Catholic Perspectives on Sport. From Medieval to Modern Times, New Jersey: Paulists Press, 2012, p. 103. 
privation, not just a deficiency.' R5 speaks similarly: 'That is a topic for whole-church discussion precisely in our situation! I wish it had come earlier.' R12, a doctor of the Catholic faith, says the reverse: 'No, although it is interesting. But is it needed?'

\section{Conclusion}

The statements of the Popes correspond to the Christian vision of the human being who was created in the image of God as an inseparable unity of body and soul. From this starting position both Popes state that sporting activity is not concerned only with the physical dimension of the human being, but that it affects his entire existence. So both the pros and the cons of these activities affect the soul and the body, which are not conceived as individual components, but as points of view from which the human being can be perceived. The Popes agree in evaluating the consequences of sport's effect on the human being. The obvious positive aspects at the individual level include relaxing from tension or the stereotype of everyday life. By stimulating self-control, sport also contributes to the harmonious development of the individual. Extensive space was also devoted to the interpersonal efficacy of sport, which can to a great extent contribute to removing interpersonal barriers and perfecting the cooperation necessary for constructing society. This element was given extensive space especially in the texts by Pope John Paul II, who presents it as an instrument of overcoming the differences not only between individuals, but even between nations. So according to him contemporary sport can contribute to solving global problems.

The two Popes also pointed out the dangers that can accompany the world of sport. However, they did not focus their attention on the negative effect of sport on the human being, but rather on the way in which sport is affected by society, which can harm it especially with an overt emphasis on commercialisation or by encouraging the cult of the body and achievement. But purifying sport in the spirit of mutual respect among the participants can be beneficent to perceiving competition as such. ${ }^{27}$ The issue of the compatibility of competition and the Christian faith is a topic to which an increasing number of theologians concerned with sport have been devoting space recently. ${ }^{28}$ So John Paul II and Benedict XVI repeatedly expressed an idea which is topical precisely today, when competition can be recognised as one of the main models of social life or worldview.

The second part of the study presents the way in which Czech theologians answer particular questions connected with the body and sport. While the answers to questions concerning theological anthropology were prevalently in agreement, the evaluation of sport manifests an (often extensive) variability. While one part of the respondents evaluated it in a similarly positive spirit as with the two Popes, others find it neutral or rather insubstantial. The question also remains how the significant group who refused to participate in the survey ought to be interpreted.

The statements of the Popes and those of the Czech theologians agree on the issue of sport's beneficence to the individual. The most frequently cited was the ability to overcome the self and

27 This idea recurs especially in Pope John Paul II.

28 Cf. () Jeremy TREAT, More than a Game: A Theology of Sport (on-line), at: http://tgc-documents.s3.amazonaws.com/themelios/Themelios40.3.pdf\#page $=12$, accessed 12th March 2015; Peter MAIER, Christianity and Competition Workbook, Missouri: Concordia Publishing House, 2010; Shirl HOFFMAN, Good Game: Christianity and Culture of Sports, Texas: Baylor University Press, 2010; Donald DEARDORFF and John WHITE, The Image of God in Human Body: Essays on Christianity and Sports, Wales: The Edwin Mellen Press, 2008. 
mastering self-discipline. These traits are often placed in context with ascetic practice. The transcendental character of sport was only rarely acknowledged, with reference to integral human development, which can be metaphorically conceived as a path to God. The interpersonal dimension of sport, which takes the central position in the papal texts, was altogether absent from the statements of Czech theologians. As far as the negative elements of sport are concerned, most answers warned against idolising it and also against excessive emphasis on some of its attributes (physical performance, beauty, etc.), which can lead to establishing a cult of the body or of beauty.

Another difference concerns the negative elements of sport. While Czech theologians speak of the way in which sport can negatively affect the human being, the papal statements describe rather the damage that sport can suffer from human society. This difference reveals the different conception of sport as such. While the Popes perceive it as a virgin space susceptible to external influences and very often call for its purification, the answers provided by Czech theologians present it rather as a field bringing along its own dangers. Such an evaluation can, in the author's view, have two roots. One can be related to Platonic dualism, which perceives the body as less valuable in comparison with the immaterial soul. This line of thought also found its advocates in the process of forming the Christian vision of the person. The other root of this attitude is, according to the author, a perception of sport relating primarily to the physical dimension of the human being. On such a basis contemporary sport can be evaluated as an activity that is not of sufficient value and is in a way dangerous for what in this conception is more human, i.e., the soul. ${ }^{29}$ Although the 'definitive' form of dualism is conceived in opposition with the Christian model of the integral human being, its elements can in different forms be found in theological reflections throughout Church history. So the possibility cannot be excluded that they are also projected into the theological evaluation of sport in a country where this discipline has still to take firm root.

Sport is a phenomenon with a firm position in society. It can be regarded as a highly detailed depiction of the human being and the society as such. The prevalent elements of society, albeit hidden, may be apparent precisely in this space. That leads to the erroneous judgement that sport is more dangerous for the human being than other spheres of human life. According to the Christian interpretation, the human being (and the world) was created by God as good (in its entirety). But at the same time it went through the Fall and was damaged in all aspects from which it can be viewed. So it is simultaneously good and bad. The author believes that sport must be viewed in a similar way. Sport is a gift that God has given humans. But this gift, like all human matters, also reflects the sinful human character.

Sport is a place where the human being is actualised and interpersonal love is constructed. The author believes this to be the true meaning of the message communicated by the Popes in the texts presented in this study. Although the interpretation of the theological statements on sport in the Czech Republic shows a positive evaluation of its individual dimension, the author believes that it is also necessary to focus on the way in which sport helps to overcome the differences between teammates and competitors. Then the theology of sport will be able to offer a new view of a number of the current problems now arising before the Church.

29 As opposed to the body which, being material, is perishable, and therefore less valuable. In an extreme dualistic position the body can even be perceived as an obstacle in the path of the soul. 


\title{
Does the Papal Doctrine on Sport Exert Influence on Theologians in the Czech Republic? (An Analysis of Survey Results)
}

\begin{abstract}
This study deals with the theological reflection of sport. In the first part it presents the way in which sport was evaluated by John Paul II and Benedict XVI. The information on this point comes mainly from the speeches, letters and other texts in which the two Popes devoted extensive space to sport. The second part of the study presents the answers to questions concerning the body and sport, which the author presented to a selected specimen of theologians in the Czech Republic. The study aims to provide the possibility to compare these two types of statements. The papal statements and the addressed theologians mostly agree on the question of how sport is beneficial to the individual. But the selected group of theologians made no statement regarding the interpersonal or global aspect of sport. The author proposes aiming further research in this direction.
\end{abstract}

Keywords: John Paul II, Benedict XVI, theology of sport, body, soul, community

\section{Author contact}

\section{Vojtěch Svoboda, M.Sc.}

University of South Bohemia, České Budějovice

Faculty of Theology, Department of Philosophy and Religious Studies

Kněžská 8, 37001 České Budějovice

svobov04@tf.jcu.cz 